\title{
The Effect of Renewable Energy Technology Uptake by the Hotel Sector
}

\author{
Dhirasasna, N. ${ }^{\text {a, }}$, Sahin, O. ${ }^{\text {bc }}$, Becken,.$^{\text {a }}$ \\ ${ }^{a}$ Griffith Institute for Tourism, Griffith University, ${ }^{b}$ Griffith School of Engineering, Griffith University, \\ ${ }^{c}$ Griffith Climate Change Response Program \\ Email: nina.dhirasasna@griffhuni.edu.au
}

\begin{abstract}
Renewable energy technology (RET) is promoted to combat climate change, reduce poverty and reduce reliance on fossil fuels (UNEP, 2011). However, its impacts need to be managed to promote sustainable growth. RET has several impacts, for example on human health through wind turbine syndrome and RET-work related accidents; on social inequality because some RET incentive policies may benefit certain groups in society; on the environment during its production; and on centralised distribution networks.
\end{abstract}

This research focuses on the hotel sector because of its relatively high energy intensity compared with other commercial buildings; and also because of its embeddedness in local communities and environments. The results of a systematic quantitative literature review reveal that studies about the impact of RET deployment in the hotel sector are currently absent. Moreover, existing studies that explore the effect of RET deployment use a linear approach rather than a holistic systems approach. The systems approach provides a framework for dealing with dynamic complexity, for seeing patterns of change rather than static 'snapshots'. The overall aim of this research is to analyse RET deployment strategies in the hotel sector and to identify suitable strategies that: (a) balance environmental, social and economic risks and benefits; and (b) promote sustainable growth of RET deployment.

This conference paper presents the result of the first stage of this research including the typologies of variables that influence the deployment of RET in the hotel sector in Queensland, Australia. The data were collected from stakeholders, and were analysed using a structural analysis with the MICMAC approach. The results show that the respondents has rated 'the reliability of electricity produced by RET' and 'a tourist comfort' as influential variables and 'whether the hotel has green program' and 'energy storage or not' as dependent variables.

The next step in this research is to develop a causal loop diagram in a stakeholder engagement workshop to identify underlying systems structures likely to influence a hotel deployment decision in RET within Queensland, Australia. Details of this workshop are outlined in this paper. A final causal loop diagram will be used to develop a simulation model to suggest improvement to hotel RET deployment strategies that balance environmental, social and economic risks and benefits.

Keywords: $\quad$ Renewable energy technology, hotel, impact, deployment, systems thinking 


\section{INTRODUCTION}

Overall, the tourism industry has experienced rapid growth and become one of the fastest growing industries globally (UNWTO, 2017). It has close ties with local communities, and hence, has become a key driver for socio-economic development in many countries (UNWTO, 2017). Tourism, however, requires energy, and its consumption of fossil fuels contributes to climate change. In particular, the transportation and the accommodation sectors generate approximately $5 \%$ of the world's greenhouse gas emissions (GHG) (UNWTO, 2017). At the same time, climate change is having a significant impact on tourist destinations such as: changes in environmental conditions; reduced attractiveness of destinations; compromised destination reputation all of which lead to a possible shift in tourist destination choice and reduced cash flow in affected areas (Meynecke et al., 2017; Moreno \& Becken, 2009; Scott et al., 2012; Shakeela \& Becken, 2014). As climate change is driven by fossil fuel combustion (IPCC, 2014), decarbonising electricity generation is one of the key mitigation strategies (International Energy Agency, 2014). Renewable energy sources offer a low level of GHG emission and are abundantly available globally (IPCC, 2014). Hence, this research agrees with this mitigation strategy and supports the promotion of renewable energy technology (RET). However, little is known about the impacts of RET deployment in the hotel sector on its society in which the hotel is located. This research aims to investigate the hotel sector and the impacts of related RET deployment strategies.

\section{LITERATURE REVIEW}

The hotel sector has several positive impacts on the local economy such as creating new jobs, supporting the local economy, stimulating infrastructure development such as airports and airstrips, tarred roads; and improving social services such as banking, health, telecommunications, and access to electricity (Mbaiwa, 2004; Peric \& Niksic Radic, 2016). However, hotels consume large amounts of energy, particularly electricity for services such as air conditioning, space and water heating, lighting, lifts, and kitchen equipment (Karagiorgas et al., 2007). Reducing electricity consumption in the hotel sector is perceived to be constrained by levels of guest comfort to retain a customer base and encourage return visits (Borkovic et al., 2008). Hotels (and their growth) can become a burden to destinations that have limited electricity supply particularly those located in regional, remote, or environmentally sensitive areas such as World Heritage sites, national parks, and islands (Dascalaki \& Balaras, 2004). These areas frequently have high energy costs and low security of energy supply (Dascalaki \& Balaras, 2004). Some stand-alone hotels rely on diesel generators which further emit GHG through combustion (Hossain et al., 2017). This presents an opportunity for promoting RET deployment in the hotel sector.

Deploying RET in the hotel sector is also crucial to maintain its competitive position. First, there is an increasing demand for green hotels from tourists who are committed to environmental management (Yusof \& Jamaludin, 2013). Failing to adopt environmentally friendly practices, a hotel may lose potential customers to other green hotels (Butler, 2008). Second, RET can reduce hotel energy costs, thus improving long-term profitability (Yusof \& Jamaludin, 2013). Lastly, adopting RET improves and adds value to the hotel image (Perramon et al., 2014). Complying with environmental regulations also prevents hotels from being penalised or shut down (Yusof \& Jamaludin, 2013). Despite the benefits and urgency to deploy RET in the hotel sector, the current adoption of RET is quite low, with the exception of thermal solar in some countries (Karagiorgas et al., 2006). Several factors contribute to the low uptake, including (1) shortage or lack of investment funds, financial factors, and uncertainty around payback time; (2) lack of experienced engineers who can support the RET adaptation in the hotel; (3) lack of information and follow up; (4) low feasibility, viability, and quality of products; (5) difficulty of integrating solar collectors in a traditionally designed hotel such as those located in the Mediterranean basin (Dascalaki \& Balaras, 2004).

A lack of empirical research investigating the RET transitioning in the hotel sector is also evident, based on our preliminary literature review using a systematic quantitative method outlined by Pickering et al. (2015). Original research papers published in English language academic journals until November $28^{\text {th }} 2016$ were obtained by searching electronic databases including Science Direct, Scopus, ProQuest, Sage, and Web of Science. The keywords used in these searches were: 'hotel', 'motel', 'caravan park', 'tourist accommodation', 'resort', 'guest service*', 'camping ground', 'tent', 'camp', 'lodge', 'inn', 'RV park', 'apartment', 'caravan park', 'bungalow' and a combination of 'renewable energy', 'solar power', 'wind power', 'hydro power', 'geothermal', 'microgrid'. Review papers, book chapters, literature reviews, news, bulletins, datasets and research notes were excluded. Reference lists of these papers were used to find additional academic papers. Inclusion criteria were: 1) research whose data were collected from the existing or modelled tourist accommodation; 2) research results of RET must be electricity, but multi-purpose functions such as cooling, heating and power are included; 3) electricity produced from RET must be used to support the tourist accommodation; and 4) fuel cells whose hydrogen is fuelled by renewable energy. Water pumps, desalination 
units, and electric cars were excluded even if they are used in tourist accommodation and fuelled by renewable energy resources. A total of $52(\mathrm{~N}=52)$ original research journal papers were identified that studied hotels and RET. Three key research themes of these papers emerged: technology application studies $(n=31,60 \%)$, energy management $(n=14,27 \%)$, and tourist and hotelier perceptions of RET $(n=7,13 \%)$. This result indicates that there is a gap in the literature regarding RET deployment in the hotel sector, particularly in relation to RET deployment strategies and impacts of this decision. Investigating possible impacts from RET deployment in the hotel sector for future investment strategies is crucial. This is because the hotel often has a close relationship with the local economy and environment.

The result of this literature review also illustrates that most studies on the impact of RET took a narrow approach to evaluate the impact of RET. RET have high environmental and socio-economic benefits (Tsoutsos et al., 2005, Saidur et al., 2011, Marques \& Fuinhas 2012). However, some negative impacts of RET do exist such as health-related effects from exposure to wind turbine noise (Pedersen, 2011), promoting social inequality as a result of RET incentives policies that benefit some society members (Stewart, 2016); environmental risks from rare-earth materials which are required to produce solar and wind energy technologies (Gabin, 2015); and unequal distribution of employment (McCombie \& Jefferson, 2016). Previous research regarding negative impacts of RET focuses on partial aspects and displays problems in a linear fashion. However, all problems are linked together as a system, hence, displaying a problem in a linear fashion cannot capture the connectivity of all problems. Therefore, this research aims to investigate the continuity of RET transitioning impact through the application of a system dynamics modelling.

The first objective of this research is to determine the variables that influence RET deployment decision in the hotel sector. This is approached by a structural analysis with the Cross-Impact Matrix Multiplication Applied to Classification (MICMAC) (Godet, 2001). The second objective of this research is to develop a dynamic hypothesis for RET deployment in the hotel sector in a case study area (Queensland, Australia). This is done by developing a causal loop diagram (CLD) that explains the variables involved in RET deployment decision in the hotel sector, and pieces together information about system structure collected from stakeholders' crossimpact matrix. By achieving these objectives, this research offers an alternative approach to understand the implications of RET deployment decisions in the hotel sector.

This paper presents the findings of the first step from applying a system thinking approach (problem articulation). The development of a system dynamics model for RET deployment in the hotel sector in Queensland, Australia is the subject of an ongoing $\mathrm{PhD}$ project. Its overarching goal is to analyse RET deployment strategies in the hotel sector and identify suitable strategies that: (a) balance environmental, social and economic risks and benefits; and (b) promote sustainable growth of RET deployment.

\section{RESEARCH METHOD}

\subsection{Study Area}

Queensland is an important tourism destination within Australia and internationally. Between 2014 - 2015 , Queensland's direct and indirect tourism activities generated AUD\$23 billion or equivalent to 7.5\% of the total Queensland Gross State Product (Tourism and Events Queensland, 2017). However, climate extremes such as floods, droughts, heatwaves and bushfires are prominent in Queensland (Queensland Government, 2016). Impact on the tourism industry includes: coral bleaching as a result of increasing sea surface temperature; reduction of rainforest areas particularly the fragmented Wet Tropics of Queensland due to increasing temperature and reducing rainfall; and damaging the tourism infrastructure and popular environmental sites from flooding (Australian Government, n.d.; Queensland Government, 2016). Between 2003 - 2004, the tourism industry in Queensland produced a total of $13.860 \mathrm{Mt}$ of GHG emissions (Tourism Queensland, 2010). Nearly half (48\%) of these emissions or $6.602 \mathrm{Mt}$ were the result of activities including air and vehicle travel to and from Queensland, Queensland hotels, and tour and attraction operators (Tourism Queensland, 2010).

At 4\%, Queensland has the lowest share of RET penetration in Australia, compared with Tasmania (99.9\%), Southern Australia (41.3\%), Western Australia (12.1\%), Victoria (12.1\%), and New South Wales (7.7\%) (Clean Energy Council, 2015). Lack of large-scale investments has contributed to Queensland's low share of RET generated electricity and undermined the nation's highest uptake of rooftop solar installation (Department of Industry and Science, 2015). This is despite the fact that retail electricity prices have increased in Queensland after its deregulation in 2016 (Phillips, 2016). Hence, promoting RET deployment in the hotel sector in Queensland is one of the options that could reduce GHG emissions, reduce the impact of increasing power bill, and assist Australia to reach its climate change goal. 
Overall, there are five steps within the system modelling method: problem articulation, dynamic hypothesis, formulation, testing, and policy formulation and evaluation (Sterman, 2001b). Figure 1 displays the systems modelling process and the data acquisition methods of this research. To date, we have implemented the first step in order to understand the implications of RET deployment decisions in the hotel sector in Queensland, Australia.

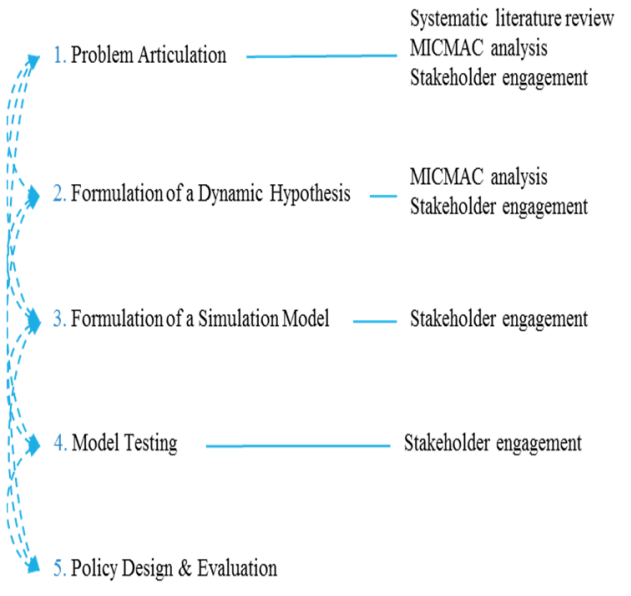

Figure 1. Systems Approach step-by-step Modelling Process.

\subsection{Problem articulation}

To develop a conceptual model, this research has applied a structural analysis using MICMAC approach developed by Godet (Godet, 2000). A structural analysis is a method that allow stakeholders to describe the links between variables in the system using a matrix (Sahin et al. 2013). In this research, MICMAC approach is used to map the influence and independence of these variables (Veltmeyer \& Sahin, 2014). The first step of structural analysis is to list the variables (Godet, 2000). According to the systematic quantitative literature review, 81 variables concern renewable energy and the hotel sector. After consulting with three academics from the tourism and engineering schools, a final list of 34 variables was developed. Variables were deleted if they were irrelevant to the research objectives and/or their definitions were overlapped. When there was disagreement to $\mathrm{keep} /$ delete variables between academics, weights were given to the academic expertise in that area. Many variables were

deleted because they were overlapping in their definitions. The refined list of variables was then used in the second step of a structural analysis to describe and rank the relationships between variables based on the expert knowledge (Onyango et al. 2016). A refined list of variables were sent to three individuals (a hotel engineer, a hotel operation manager, and a hotel accountant). Each individual was required to enter their judgement on the direct relationship between the variables and their intensities (none $=0$, weak $=1$, moderate $=2$, and strong $=$ 3 ) into the corresponding matrix cell $(34 \times 34=1,156$ cells). These responses are presented in this paper.

The third step is to identify key variables by using MICMAC approach which calculates the influence and dependency between variables (Sahin et al. 2013). The results indicate that each participant perceived key variables of renewable energy and the hotel sector differently. The most influential variables on renewable energy uptake in the hotel sector across the three respondents are 'reliability of electricity produced by RET' and 'tourists' level of comfort'. The results also indicate that 'RET technological development', 'customers' perceived level of comfort and value', and 'the hotel's physical environment in the form of ambience particularly lighting, heating, and cooling' have an influence on whether a hotel will deploy RET or not. We also found that all three respondents agree that whether a hotel will deploy RET or not depends on 'the existence of social and environmental responsibility program in a hotel', and 'energy storage'. We hypothesise that the hotel operation manager and accountant rated hotel and tourist related variables more than an engineer possibly because of the nature of their vocations.

Table 1. The Top 10 Most Influential and Dependent Variables Rated by Respondents.

\begin{tabular}{|c|c|c|c|}
\hline & Engineer & Operation Manager & Accountant \\
\hline
\end{tabular}




\begin{tabular}{|c|c|c|c|}
\hline 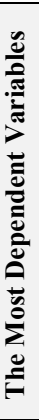 & $\begin{array}{l}\text { 1. Eco-friendly hotel design } \\
\text { 2. Availability of workforce } \\
\text { 3. Reliability/availability of non- } \\
\text { renewable supply } \\
\text { 4. Hotel existence of Green program } \\
\text { 5. Non-renewable energy cost } \\
\text { 6. Hotel accessibility to the electrical } \\
\text { grid } \\
\text { 7. Tourist types } \\
\text { 8. Tourist perception of RET as a } \\
\text { reliable energy source } \\
\text { 9. Hotel availability of space } \\
\text { 10. Energy storage }\end{array}$ & $\begin{array}{l}\text { 1. Hotelier perception of RET as } \\
\text { 2elling point } \\
\text { 2. Hotel technical capacity } \\
\text { 3. Hotelier perception of RET } \\
\text { financial benefits } \\
\text { 4. Hotel existence of Green program } \\
\text { 5. Hotel availability of finance } \\
\text { 6. Hotel energy demand profile } \\
\text { 7. Hotelier awareness of energy } \\
\text { 8. Energy storage } \\
\text { 9. Eco-friendly hotel design } \\
\text { 10. tourist perceived quality of service }\end{array}$ & $\begin{array}{l}\text { 1. Hotelier perception of RET as } \\
\text { selling point } \\
\text { 2. Hotel existence of Green program } \\
\text { 3. Hotel availability of finance } \\
\text { 4. Hotel energy demand profile } \\
\text { 5. Hotelier perception of RET } \\
\text { financial benefits } \\
\text { 6. Eco-friendly hotel design } \\
\text { 7. Energy storage } \\
\text { 8. Hotel rating } \\
\text { 9. Hotel technical capacity } \\
\text { 10. Hotelier awareness of energy } \\
\text { conservation method }\end{array}$ \\
\hline
\end{tabular}

\subsection{Formulating a dynamic hypothesis}

Formulating a dynamic hypothesis involves mapping the system and its feedback structure. In this research, we have selected CLD because of its simple visualisation (Sterman, 2001a). This research has three stakeholder engagement stages to validate the CLD structure. The overall objective of stakeholder engagement is to confirm if the CLD coincides with their opinions about RET and the hotel sector. The stakeholders can: add/delete variables and arrows that represent the causal relationship between pairs of variables; amend variable names and definitions; and indicate its polarity whether the cause and effect of each arrow moves in the same direction "S" or opposite direction "O". We apply an iterative process by which changes of CLD from one meeting will be presented in the next meeting. Disagreement in whether a polarity was " $O$ " or " $\mathrm{S}$ " will be addressed in stage 3 of stakeholder engagement workshop.

In the first stage, we developed a preliminary CLD based on the geomean matrix results completed by the three respondents in the previous step. This preliminary CLD will be presented to these respondents during a oneon-one meeting in order to confirm if the CLD coincides with their opinions about RET and the hotel sector. The final result from these meetings will be a working CLD. In the second stage, we will present the working CLD to other stakeholders in a one-on-one interview. These other stakeholders were identified by two academics from the engineering and tourism schools using a rainbow diagram, and classified based on the degree they can affect or be affected by the problem (Chevalier \& Buckles, 2008). The results of this interview is a confirmed CLD. In the third stage, the confirmed CLD will be presented in a stakeholder engagement workshop. In this workshop, all of the stakeholders from stage 1 and 2 and those who have not engaged in this research will be invited. This gathering of stakeholders provides an opportunity for them to discuss should there be a different perception in polarities.

\section{CONCLUSION AND FUTURE WORK}

The aim of this research is to investigate the hotel sector and the impacts of its RET deployment strategies. The hotel sector has opportunities to use RET to maintain its competitive position, add value to the hotel image, and reduce hotel energy consumption. Despite these benefits, hotel RET deployment rate is low, and there is a lack of research in this topic are as seen from the systematic quantitative literature review result. In addition, the resultant literature review illuminates the limitation of previous research about RET impacts which includes looking at one partial aspect of an impact while ignoring their continuity. This research offers an alternative approach to understand the implications of RET decisions in the hotel sector by using a systems approach. Reporting in this conference paper is the result of the first stage of system modelling- problem articulation. By applying a structural analysis with the MICMAC approach, the results from three stakeholders show that 'the reliability of electricity produced by RET' and 'tourists' level of comfort' are influential variables on RET uptake in the hotel sector. 'The existence of green program' and 'energy storage' were also rated as dependent variables. The next stage of this research is to build a CLD model and confirm it in a stakeholder engagement workshop.

\section{REFERENCES}

Australian Government (n.d.). Climate Change Impacts in Queensland. Retrieved from http://www.environment.gov.au/climate-change/climate-science/impacts/qld

Borkovic, Z. H., B. Kulisic, and M. Zidar (2008). Energy Audit-Method for Energy Conservation in Hotels. Tourism and Hospitality Management, 14(2), 349-358.

Butler, J. (2008). The compelling "hard case" for "green" hotel development. Cornell Hospitality Quarterly, 49(3), 234-244. 
Dhirasasna, N. et al. The Effect of Renewable Energy Technology Uptake by the Hotel Sector

Chevalier, J., and D. Buckles (2008). In SAS: A Guide to Collaborative Inquiry and Social Engagement. New Delhi: SAGE Publications India Pvt Ltd. Retrieved from http://methods.sagepub.com/book/sas2-social-analysis-systems. doi:10.4135/9789351507734

Clean Energy Council (2015). Clean Energy Australia Report 2015. Retrieved from https://www.cleanenergycouncil.org.au/policy-advocacy/reports/clean-energy-australia-report.html

Dascalaki, E., and C. A. Balaras (2004). XENIOS - a methodology for assessing refurbishment scenarios and the potential of application of RES and RUE in hotels. Energy and Buildings, 36(11), 1091-1105. doi:10.1016/j.enbuild.2004.03.007

Department of Industry and Science (2015). Energy White Paper. Retreived from https://industry.gov.au/EnergyWhitePaperataglance/index.html

Gabin, B. (2015). Sustainable Development of China's Rare Earth Industry within and without the WTO. Journal of World Trade, 49(3), 495-515.

Godet, M. (2000). The art of scenarios and strategic planning: Tools and pitfalls. Technological Forecasting and Social Change, 65, 3-22.

Godet, M. (2001). Creating futures - Scenario Planning as a Strategic Management Tool. Paris, Economica.

Hossain, M., S. Mekhilef, and L. Olatomiwa (2017). Performance evaluation of a stand-alone PV-wind-dieselbattery hybrid system feasible for a large resort center in South China Sea, Malaysia. Sustainable Cities and Society, 28, 358-366. doi:10.1016/j.scs.2016.10.008

International Energy Agency (2014). Annual Report 2013. France, International Energy Agency. Retreived from https://www.iea.org/publications/freepublications/publication/2013_AnnualReport.pdf

IPCC. (2014). Summary for Policymakers In Climate Change 2014, Mitigation of climate change. Contribution of Working Group III to the Fifth Assessment Report of the Intergovernmental Panel on Climate Change. Cambridge, United Kingdom and New York, NY, USA: Cambridge University Press.

Karagiorgas, M., T. Tsoutsos, V. Drosou, S. Pouffary, T. Pagano, G.L. Lara, and J.M. Melim Mendes (2006). HOTRES: renewable energies in the hotels. An extensive technical tool for the hotel industry. Renewable and Sustainable Energy Reviews, 10(3), 198-224. doi:10.1016/j.rser.2004.09.012

Karagiorgas, M., T. Tsoutsos, and A. Moiá-Pol (2007). A simulation of the energy consumption monitoring in Mediterranean hotels: Application in Greece. Energy and Buildings, 39(4), 416-426. doi:10.1016/j.enbuild.2006.07.008

Marques, A.C., and J.A. Fuinhas (2012). Is renewable energy effective in promoting growth?, Energy Policy, $46,434-442$.

Mbaiwa, J.E. (2004). The Socio-cultural Impacts of Tourism Development in the Okavango Delta, Botswana. Journal of Tourism and Cultural Change, 2(3), 163-185.

McCombie, C., and M. Jefferson (2016). Renewable and nuclear electricity: Comparison of environmental impacts. Energy Policy, 96, 758-769. doi:10.1016/j.enpol.2016.03.022

Meynecke, J.-O., R. Richards, and O. Sahin (2017). Whale watch or no watch: the Australian whale watching tourism industry and climate change. Regional Environmental Change, 17(2), 477-488. doi:10.1007/s10113-016-1034-Z

Moreno, A., and S. Becken (2009). A climate change vulnerability assessment methodology for coastal tourism. Journal of Sustainable Tourism, 17(4), 473-488. doi:10.1080/09669580802651681

Onyango, E.A., O. Sahin, C. Chu, and B. Mackey (2016). An Integrated Modelling Approach to Climate Change and Malaria Vulnerability Assessments. Paper presetned at The 8th International Congress on Environmental Modelling and Software, Toulouse, France, July 11.

Pedersen, E. (2011). Health aspects associated with wind turbine noise-Results from three field studies. Noise Control Engineering Journal, 59(1), 47.

Peric, J., and M. Niksic Radic (2016). Development impact of FDI in hotel: Case study of Terme Tuhelj in Croatia. Almatourism - Journal of Tourism, Culture and Territorial Development, 7(13), 66-78. doi:10.6092/issn.2036-5195/5983

Perramon, J., M.M. Alonso-Almeida, J. Llach, and L. Bagur-Femenias (2014). Green Practices in restaurants: impact on firm performance. Operations Management Research, 7(1-2), 2-12.

Pickering, C., J. Grignon, R. Steven, D. Guitart, and J. Byrne (2015). Publishing not perishing: how research students transition from novice to knowledgeable using systematic quantitative literature reviews. Studies in Higher Education, 40(10): 1756-1769.

Phillips, S. (2016). Queensland electricity: Consumers to pay more as deregulation kicks in. The Courier Mail. Retreived from http://www.couriermail.com.au/news/queensland/queensland-electricityconsumers-to-pay-more-as-deregulation-kicks-in/news-story/3d6f4b0b0df582930ddc0fde6c6d8334 
Queensland Government (2016). Draft Climate Change in Queensland. Retrieved from http://www.ehp.qld.gov.au/assets/documents/climate/queensland-climate-change-impactsummary.pdf

Sahin, O., R. Richards, and M. Sano (2013). Integrated Modelling Approach for Climate Change Adaptation: The Case of Surf Life Saving Australia. Paper presented at the 20th International Congress on Modelling and Simulation, Adelaide, Australia, December 1-6.

Saidur, R., N.A. Rahin, M.R. Islan, and K.H. Solangi (2011). Environmental impact of wind energy. Renewable and Sustainable Energy Reviews, 15(5): 2423-2430.

Scott, D., C.M. Hall and S. Gössling (2012). Tourism and Climate Change: Impacts, Adaptation and Mitigation. Great Britain: Routledge.

Shakeela, A., and S. Becken (2014). Understanding tourism leaders' perceptions of risks from climate change: an assessment of policy-making processes in the Maldives using the social amplification of risk framework (SARF). Journal of Sustainable Tourism, 1-20. doi:10.1080/09669582.2014.918135

Sterman, J.D. (2001a). Business Dynamics: System Thinking and Modeling for a Complex World. Irwin McGraw-Hill.

Sterman, J.D. (2001b). System dynamics modeling: Tools for learning in a complex world. California Management Review, 43(4), 8-25.

Stewart, R.A. (2016). Why you should stay on the grid, even with your solar-powered batteries. Retrieved from https://theconversation.com/why-you-should-stay-on-the-grid-even-with-your-solar-poweredbatteries-41765

Tourism and Events Queensland (2017). Tourism Economic Key Facts. Retrieved from https://cdnteq.queensland.com/ $/$ media/22e72aae883d4fd7bffdab8fa8ee352f.ashx? vs $=1 \& \mathrm{~d}=20170412 \mathrm{~T} 15332$ 7

Tourism Queensland (2010). The Carbon Footprint of the Queensland Tourism Industry. Retrieved from https://cdnteq.queensland.com/ /media/81bfdddcf04f409299547d46ea987aab.ashx?vs=1\&d=20140 $512 \mathrm{~T} 080633$

Tsoutsos, T., N. Frantzeskaki, and V. Gekas (2005). Environmental impacts from the solar energy technologies. Energy Policy, 33(3), 289-296.

UNEP. (2011). Towards a Green Economy: Pathways to Sustainable Development and Poverty Eradication. Retrieved from https://sustainabledevelopment.un.org/index.php?page=view\&type $=400 \& n r=126 \& m e n u=35$

UNWTO. (2017). Why Tourism? Retrieved from http://www2.unwto.org/content/why-tourism

Veltmeyer, J., and O. Sahin (2014). Modelling climate change adaptation using cross-impact analysis: an approach for integrating qualitative and quantitative data. Paper presented at the Proceedings of the 7th International Congress on Environmental Modelling and Software (iEMSs 2014), San Diego, CA, USA.

Yusof, Z.B., and M. Jamaludin (2013). Green approaches of Malaysian green hotels and resorts. ProcediaSocial and Behavioral Sciences, 85, 421-431. doi:10.1016/j.sbspro.2013.08.371 